\title{
Sikap Remaja di Media Sosial Instagram saat Musim Pandemi Covid 19
}

\author{
Dianis Izzatul Yuanita ${ }^{1}$, Beti Malia Rahma Hidayati ${ }^{2}$ \\ 'Institut Agama Islam Tribakti, ,2Institut Agama Islam Tribakti \\ 1'dianisizzatulyuanita@gmail.com, ${ }^{2}$ tulhidayati@gmail.com
}

\begin{abstract}
Social media is not the only thing that peoples need nowdays, but it is a part of society from young to old age. Teenagers become one of the active users of social media such as Instagram. Various studies focus on researching on social media Instagram. As for this research, researchers aimed at figuring out how the teenagers at social media instagram are behaving during Covid 19 pandemic season. This study uses qualitative research methods, with analysis of phenomenological approaches and social action theory. It is known that attitude is part of the learning process that comes from interaction and perception. As a results of this study, researchers have expressed the teenagers attitude on on social media Instagram in the pandemic covid 19 season of teenagers boys tend toward a positive negative attitude and the teenager girls tend toward a negative attitude. Based on self-interest, social identification, and value relevance indicated in social media, the teenager boys focuses on his talents and interests, while the teenagers girls focus on imitating idol figures such as artists and celebrities.
\end{abstract}

Keywords: Social Action Theory, Teenager, Social Media, Instagram.

\begin{abstract}
Abstrak
Media sosial bukan hanya menjadi kebutuhan masyarakat saat ini, akan tetapi sudah menjadi bagian dari kehidupan masyarakat dari usia muda hingga lanjut usia. Remaja menjadi salah satu pengguna aktif dalam media sosial seperti instagram. Berbagai penelitian berfokus untuk meneliti tentang media sosial instagram. Adapun dalam penelitian ini, peneliti bertujuan untuk mengetahui bagaimana sikap remaja di media sosial instagram pada musim pandemic Covid 19. Penelitian ini menggunakan metode penelitian kualitatif, dengan analisis pendekatan fenomenologi dan teori tindakan sosial. Diketahui bahwa sikap merupakan bagian dari proses pembelajaran yang berasal dari interaksi dan persepsi. Hasil dari penelitian ini, peneliti mengungkapkan sikap remaja di media sosial instagram pada musim pandemic covid 19 untuk remaja laki-laki cenderung ke arah positif sedangkan untuk remaja perempuan cenderung ke arah negatif. Berdasarkan self interest, identifikasi sosial, dan relevansi nilai yang ditujukkan dalam media sosial, remaja laki-laki berfokus dengan menunjukkan bakat dan minatnya, sedangkan remaja perempuan berfokus pada meniru tokoh idola seperti artis dan selebgram.
\end{abstract}

Kata Kunci: Teori Tindakan Sosial, Remaja, Media Sosial, Instagram

\section{Pendahuluan}

Bulan Maret masyarakat Indonesia dikejutkan dengan virus baru, virus ini bernama Covid 19. Virus yang berasal dari Wuhan, China masuk pertama kali di Indonesia pada tanggal 02 Maret 2020. ${ }^{1}$ Virus ini terus meningkat seiring berjalannya waktu hingga Juni 2020.

1 Adityo Susilo dkk., “Coronavirus Disease 2019: Tinjauan Literatur Terkini," Jurnal Penyakit Dalam Indonesia 7, no. 1 (1 April 2020): 45, https://doi.org/10.7454/jpdi.v7i1.415., 46.

Jurnal Kopis: Kajian Penelitian dan Pemikiran Komunikasi Penyiaran Islam

Volume 03, Issue 1, Agustus 2020 
Diketahui bahwa virus Coronavirus 2019 (Covid 19) mengganggu sindrom pernapasan akut dan masuk dalam daftar salah satu penyakit yang menular. ${ }^{2}$ Dikutip dari instagram Kominfo, wilayah Jawa Tiimur menjadi wilayah terbanyak masyarakatnya yang terinfeksi Covid 19. Adapun untuk kota Surabaya menjadi kota terbanyak masyarakatnya yang terinfeksi, menyusul Sidoarjo menjadi wilayah kedua terbanyak setelah Surabaya sebagai wilayah yang warganya terinsfeksi covid 19.

Banyaknya covid 19 di wilayah Sidoarjo mempengaruhi beberapa aspek, seperti social, ekonomi, pendidikan dan budaya. Sidoarjo juga menjadi wilayah yang menerapkan Pembatasan Sosial Berskala Besar (PSBB) selama 3 jilid. Dengan adanya PSBB dan protocol dari pemerintah untuk Work From Home, siswa dari usia sekolah hingga mahasiswa yang menempuh bangku perkuliahan melaksanakan pengajaran dari rumah. Selah satu yang terdampak adanya covid 19 yakni remaja usia sekolah. Proses pembelajaran dari rumah tentunya menjadikan remaja lebih sering membuka media social untuk berinteraksi dan berkomunikasi di waktu yang senggang, dibandingkan dengan mereka ketika belajar di sekolah.

Remaja rata-rata aktif menggunakan media social selama musim pandemic covid 19. Keaktifan dan intensitas penggunaan yang lama dipengarhi karena media social memiliki kecepatan dalam mendapatkan informasi, dan kemudahan dalam mengirimkan pesan. Dalam pandangan Psikologi, Hurlock ${ }^{3}$ menyatakan masa remaja menjadi masa individu dapat berinterinteraksi dengan berbagai kalangan masyarakat, seperti masyarakat dewasa. Penyataan Hurlock, diperkuat oleh Hinigharst dalam Sarwono yang menyatakan kewajiban seorang remaja dapat berinteraksi yang baik dengan lingkungannya seperti lingkungan keluarga, teman sebaya, dan paling utama orang tua. tentunya, dimasa pandemic covid 19 remaja sering aktif berkomunikasi dengan orang tua secara langsung, akan tetapi dalam berkomunikasi dengan teman sebaya mereka menggunakan media social.

Era digitalisasi membentuk individu yang tidak terlepas dari media social, tidak terkecuali remaja. Hal ini berkaitan dengan tiga alasan yang mendasari keperluan seseorang menggunakan media sosial, yakni, pertama, manusia sebagai makhluk untuk saling bertukar informasi. Kedua, di abad ke-21 revolusi di bidang teknologi informasi dan komunikasi yang berbasis internet membuat masyarakat kebanjiran informasi. Ketiga, meningkatnya jumlah pengguna internet setiap tahunnya, hal ini ditunjukkan oleh hasil survey Asosiasi Penyelenggara Jasa Internet Indonesia (APJII). ${ }^{4}$

Sebuah data perusahaan melakukan riset marketing dan media sosial MarkPlus Insight, 93\% data menjelaskan bahwa pengguna internet di Indonesia menggunakan internet untuk mengakses media sosial, untuk chatting 59\%, game 18\%, mengunduh $41 \%$, dan untuk

\footnotetext{
${ }^{2}$ Eman Supriatna, "WABAH CORONA VIRUS DISEASE (COVID 19) DALAM PANDANGAN ISLAM," SALAM: Jurnal Sosial dan Budaya Syar-i 7, no. 6 (14 April 2020), https://doi.org/10.15408/sjsbs.v7i6.15247.555

3 Virgia Ningrum Fatnar dan Choirul Anam, "KEMAMPUAN INTERAKSI SOSIAL ANTARA REMAJA YANG TINGGAL DI PONDOK PESANTREN DENGAN YANG TINGGAL BERSAMA KELUARGA" 2, no. 2 (2014): 5.

${ }^{4}$ Lihat lebih jelas dalam Cawidu I., "Pemanfaatan media sosial" (Rapat Kerja Pustakawan XX Ikatan Pustakawan Indonesia., Bandung: ipi.perpusnas.go.id, 2016).
}

Jurnal Kopis: Kajian Penelitian dan Pemikiran Komunikasi Penyiaran Islam Volume 03, Issue 1, Agustus 2020 
berbelanja 15\%. Hal ini guna menjelaskan bahwa Indonesia menjadi sasaran pangsa pasar dalam penggunaan sosial media dan aplikasi pengirim pesan instan. ${ }^{5}$

Media sosial memberi manfaat kepada penggunanya, seperti komunikasi, kolaborasi, komunitas, dan kesepakatan untuk kecerdasaran kolektif. Media sosial bukan sekedar tren atau gaya hidup, tetapi media sosial menjadi bagian dari kehidupan masyarakat saat ini. Dilihat dari data Global Web Index pada tahun 2014, Indonesia menjadi negara yang memiliki pengguna media sosial paling aktif di Indonesia, yaitu sebesar 79,7\% dibandingkan negara lain, seperti Filipina 78\%, Malayasia 72\% dan Cina 67\%. ${ }^{6}$ salah satu media social yang digemari para remaja saat ini yaitu instagram. Dikutip dari kompas.com, menyatakan bahwa pengguna aktif media social instagram di Indonesia mencapai angka 61.610.000, dengan spesifikasi gender, pengguna perempuan 50,8\% dan laki-laki 49,2\%.

Instagram merupakan aplikasi yang memiliki tiga fasilitas yang bisa dibagikan ke follower dari pemilik akun, fasilitas tersebut seperti foto, video dan teks, mulai dari video berdurasi satu menit sampai video berdurasi dua hingga lima menit melalui IGTV. Fasilitas dari instagram ini bisasa digunakan pengguna instagram untuk menunjukkan apa yang ingin dikesankan dan dipublikasikan, sebagaimana sikap maupun maupun pandangan terhadap suatu objek. Dalam hal ini remaja dapat menunjukkan sikap negative maupun sikap positif yang di instagram.

Menurut Fazio dan Roskos Ewoldsen, Sikap merupakan hubungan antara objek sikap (dapat berwujud apapun yang ada dalam aspek dunia social) dan evaluasi terhadap objek tersebut. Sedangkan menurut Judd dan kawan-kawan menyatakan bahwa sikap merupakan evaluasi dari bersikap menetap terhadap berbagai aspek dalam dunia social, dan tentunya evaluasi ini tersimpan kuat dalam ingatan manusia.

Sikap menjadi sesuatu yang sangat penting karena dari sikap inilah dapat mempengaruhi pola pikir dan proses individu dalam menangkap suatu informasi social. ${ }^{8}$ Sikap menjadi sesuatu yang dapat dipelajari yaitu dengan proses belajar social, seperti melalui interaksi dengan orang lain dan mengamati perilaku orang lain.

Modelling merupakan proses pembelajaran sikap melalui contoh (meniru perilaku dan tindakan orang lain. Sikap dibentuk dari bentuk perilaku dan tindakan orang lain. Selain dari proses meniru, sikap dibentuk dari proses membanding, dalam psikologi social hal ini disebut dengan proses perbandingan social (social comparison). Menurut Festinger, perbandingan social merupakan proses membandingkan diri sendiri dengan orang lain, tentang pandangan diri sendiri dalam lingkungan social apakah benar atau tidak benar. ${ }^{9}$ Sikap yang ditunjukkan remaja di media social dapat terjadi karena dipengaruhi lingkungan sekitar seperti teman sebaya dan orang tua.

Analisis teori yang digunakan dalam riset ini menggunakan analisis teori tindakan social. Max Weber menyatakan bahwa teori tindakan social merupakan bagian dari keilmuan sosiologi. Hal ini diperkuat dengan pernyataan T. Parsons yang menyatakan bahwa tindakan

${ }^{5}$ Erik Setiawan dkk., "Makna Hijrah pada Mahasiswa Fikom Unisba di Komunitas ('followers') Akun 'LINE@DakwahIslam,”" MediaTor 10,no.1 (2017): 98.

${ }^{6}$ Gita Aprianta E.B, dan Errika Dwi S.W, "Hubungan Penggunaan Media Sosial Dengan Tingkat Kepekaan Sosial di Usia Remaja," The Messenger 9, no. 1 (2017): 65.

7 Wahyunanda Kusuma Pertiwi, "Sebanyak Inikah Jumlah Pengguna Instagram di Indonesia?," Kompas.com, t.t.

${ }^{8}$ RA Baron dan Byrne D, Psikologi sosial, 10 ed. (Jakarta: Erlangga, t.t.).124

${ }^{9}$ Baron dan Byrne D.128-129

Jurnal Kopis: Kajian Penelitian dan Pemikiran Komunikasi Penyiaran Islam

Volume 03, Issue 1, Agustus 2020 
social terdapat individu yang disebut actor dalam sebuah sistem. ${ }^{10}$ Tindakan social memiliki dua hal yaitu actor dan hasil tindakan. Dalam mencapai suatu tindakan dilatarbelakangi oleh beberapa sistem kehidupan seperti sel, organ, organisme, kelompok, organisasi, komunitas, masyarakat, dan sistem supranasional. Maka dalam hal ini, tindakan social merupakan interaksi diantara sistem kehidupan atau diantara berbagai bagian dari sistem kehidupan di tingkat social. Penelitian ini bertujuan untuk mengetahui tentang sikap remaja di media social instagram pada musim pandemic covid 19.

\section{Metode}

Penelitian ini menggunakan penelitian kualitatif dengan pendekatan fenomenologis. Penelitian kualitatif adalah metode untuk mengeksplorasi dan memahami makna yang dianggap berasal dari masalah sosial atau kemanusiaan, dengan fokus pada makna individu, dan menerjemahkan kompleksitas masalah. ${ }^{11}$ William menyatakan dalam penelitian kualitatif adalah proses pengumpulan data dari pengaturan alamiah, menggunakan metode alami, yang dilakukan oleh para peneliti yang tertarik pada sesuatu yang bersifat alamiah. ${ }^{12}$ Sementara pendapat Kirk dan Muller tentang penelitian kualitatif tergantung pada pengamatan pada manusia, baik di area maupun terminologi. ${ }^{13}$

Penelitian kualitatif digunakan disini karena peneliti mengeksplorasi da memahami persoalan sosial yang terjadi pada sikap remaja di media social instagram pada musim pandemic Covid 19. Pendekatan fenomenologis adalah tradisi penelitian kualitatif pada filsafat dan psikologi merupakan akarnya, dan tujuan utama terletak pada pengalaman kehidupan manusia (sosiologi). Pendekatan fenomenologis hampir mirip dengan pendekatan hermeneutika yang menggunakan pengalaman hidup sebagai alat untuk lebih memahami suatu pengalaman hidup dalam konteks sosial, budaya, politik atau sejarah.

Penelitian ini membahas objek penelitian dengan memahami pengalaman inti dari suatu fenomena. Teori fenomenologi terutama membagi masalah bahasa sejauh mana diberikan pada peran utama dalam membentuk sebuah pengalaman. Paradigma fenomenologi berusaha memahami makna peristiwa dan kaitannya dengan orang-orang dalam situasi tertentu. ${ }^{14}$

Penelitian dengan kerangka fikir yang menggunakan Fenomenologi sikap remaja di instagram pada musim Covid 19, dan analisis teori tindakan sosial. Dimana fenomenologi menurut Pakar Komunikasi Mulyana termasuk pendekatan subyektif atau interpretatif yang memaknai manusia sebagai suatu tindakan yang tidak terlalu aktif, berbeda dengan pendekatan objektif atau behavioris dan struktural yang menganggap bahwa manusia aktif. Subyek dalam penelitian ini terdiri dari remaja tingkat SMA/SMK/MA di wilayah Sidoarjo

10 Adrian Netedu, "TALCOTT PARSONS, THE THEORY OF SOCIAL ACTION AND THE THEORY OF RATIONAL CHOICE,” Talcott Parsons, 2010, 14.

${ }^{11}$ John W. Cresswall, Research Design Pendekatan Kualitatif, Kuantitatif, dan Mixed, Edisi Ketiga (Yogyakarta: Pustaka Belajar, 2009). 4

${ }^{12}$ Lexy J. Moleong, Metodologi Penelitian Kualitatif (Bandung: PT. Rosda Karya, 2008). 3

13 Moleong. 5.

14 Moleong.14-17

Jurnal Kopis: Kajian Penelitian dan Pemikiran Komunikasi Penyiaran Islam Volume 03, Issue 1, Agustus 2020 
yang memiliki akun instagram dan memposting konten di periode bulan Maret sampai Juni 2020 .

\section{Hasil dan Pembahasan}

Dalam penelitian ini, peneliti melakukan riset terhadap 10 remaja di Sidoarjo yang memiliki akun instagram, adapun dari 10 remaja, terdiri dari 5 laki-laki dan 5 perempuan. Berikut peneliti paparkan jumlah konten yang di posting melalui Feed Instagram selama periode Maret-Juni 2020:

Tabel 1 Data Remaja yang memiliki akun Instagram

\begin{tabular}{|c|c|c|}
\hline Nama akun & Jenis Kelamin & Jumlah Post \\
\hline _riangilang & Laki-laki & 4 \\
\hline Haniffajar10 & Laki-laki & 1 \\
\hline syamsul_zoqri & Laki-laki & 1 \\
\hline Civicasilmii & Perempuan & 2 \\
\hline dion_ina10 & Laki-laki & 4 \\
\hline adrianarthur_- & Laki-laki & 3 \\
\hline Nadiarahmaa & Perempuan & 1 \\
\hline Awwdevi & Perempuan & 2 \\
\hline Marrtiir & Perempuan & 3 \\
\hline tiara oktv_ & Perempuan & 1 \\
\hline
\end{tabular}

Konten yang di post remaja di Instagram pada musim pandemic covid 19 sangat beragam. Terdapat konten yang mengintrepretasikan sikap positif maupun konten yang mengintrepretasikan sikap negative. Konten terdiri dari foto ketika berwisata sebelum covid 19, foto di warung kopi, foto tentang kampanye protocol kesehatan mencegah covid 19, foto selfi, foto wefi bersama keluarga maupun teman, foto menyambut hari raya idul fitri, foto bersama pasangan, dan foto yang menujukkan kebosananan mereka dikala karantina di rumah untuk mencegah penyebaran covid 19. Setiap foto yang menjadi bagian dalam konten dipengaruhi oleh ketertarikan hubungan, organisasi, dan cara pandang remaja tersebut.

Informasi menjadi entitas penting di media sosial karena pengguna media sosial mengkreasikan representasi identitasnya, memproduksi konten, dan melakukan interaksi berdasarkan informasi. Bagi pengguna media sosial, arsip menjadi sebuah karakter yang menjelaskan bahwa informasi telah tersimpan dan bias diakses kapanpun dan melalui perangkat apapun. Selain itu, media sosial membentuk jaringan antar pengguna yang tidak sekedar memperluas hubungan pertemanan atau pengikut (follower) semata, tetapi harus dibangun dengan interaksi antar pengguna tersebut.Simulasi Sosial. Dalam media sosial memiliki karakter sebagai medium berlangsungnya masyarakat (society) di dunia virtual. Media sosial memiliki keunikan dan pola yang dalam banyak kasus berbeda dan tidak dijumpai dalam tatanan masyarakat yang real. Konten oleh pengguna (user-generated content), dalam Media sosial konten sepenuhnya milik dan berdasarkan kontribusi pengguna atau pemilik akun. UGC merupakan relasi simbiosis dalam budaya media baru yang memberikan kesempatan dan keleluasaan pengguna untuk berpartisipasi. Hal ini berbeda dengan media lama (tradisional) dimana khalayaknya sebatas menjadi objek atau sasaran yang pasif dalam distribusi pesan. ${ }^{15}$

15 Rulli Nasrullah, Media Sosial, Perspektif Komunikasi, Budaya dan Sosioteknologi, (Bandung: Simbiosa Rekatama Media, 2015), hal. 48

Jurnal Kopis: Kajian Penelitian dan Pemikiran Komunikasi Penyiaran Islam

Volume 03, Issue 1, Agustus 2020 
Berdasarkan penjelasan yang telah dipaparkan, dapat diketahui bahwa media sosial memiliki kriteria-kriteria tertentu. Bentuk media sosial yang ada di kalangan masyarakat sangat beragam, salah satunya adalah situs jejaring sosial. Situs jejaring sosial merupakan situs yang dapat membuat pengguna terhubung ke pengguna lain melalui sebuah profil. Mengundang teman dan rekan untuk mempunyak akses ke profil pengguna lain dan dapat mengirim pesan secara instan ${ }^{16}$, seperti Instagram. Pada pembahasan penelitian ini membahas tentang sikap remaja di media social instagram pada musim pandemic covid 19.

Aspek situasi mempengaruhi sikap individu. Seperti situasi pandemic covid 19, remaja yang awalnya menghabiskan waktu di luar rumah, menjadi di dalam rumah, atau dalam bahasa saat ini bisa disebut dengan \#dirumahaja. Hubungan erat antara sikap dan situasi. Tekanan situasional menentukan seberapa jauh sikap dieskresikan dalam bentuk suatu tindakan remaja. Dalam hal ini, remaja mengeskresikan sikap melalui media social instagram. Terdapat tiga factor yang berperan penting dalam menentukan makna sikap yaitu self Interest (sejauh mana sikap mempengaruhi kehidupan atau tujuan individu, kedua identifikasi social (sejauh mana sikap mempengaruhi kelompok kepada siapa individu mengidentifikasi diri, dan ketiga relevansi nilai (sejauh mana sikap berhubungan dengan nilai-nilai pribadi.

Tipologi tindakan social yang diusulkan didasarkan pada analisis proses perkembangan reproduksi dan interaksional dalam sistem social. ${ }^{17}$ Menurut Max Weber Tindakan social memiliki beberapa kategorisasi, dalam hal ini terdiri dari: Perilaku reaktif, dimana tidak ada makna subjektif, dan umumnya hanya imitasi reaktif tidak bermakna secara social; perilaku tradisional meskipun ini mungkin melewati batas antara apa yang bermakna dan tidak bermakna; proses psikologis mungkin tidak bermakna, setidaknya dapat dilihat oleh orang lain; fenomena psikis atau psikofisik seperti kelelahan, habituasi, keadaan memori euphoria, dan variasi dalam waktu atau ketepatan reaksi individu; tindakan alami; tindakan umum; imitasi; dan perilaku murni afektif. ${ }^{18}$ tipologi tindakan social terwujud dalam sikap remaja di media social instagram, bagaimana konten yang diunggah ketika sebelum pandemic covid 19, tentu berbeda ketika setelah adanya pandemic covid 19.

Dari hasil penelitian ini sikap positif cenderung lebih banyak ditunjukkan oleh remaja laki-laki, mereka menunjukkan self interest, Identifikasi social, dan relevansi nilai. Konten yang diunggap memiliki wujud sikap yang dipengaruhi oleh lingkungan. Dalam penelitian ini, remaja laki-laki berada pada lingkungan yang baik, sehingga Nampak konten bukan sekedar konten biasa, namun terdapat nilai, seperti konten menunjukkan bakat di bidang yang diminati, dan konten kampanye protocol kesehatan dalam mencegah penyebaran covid 19. Sedangkan untuk sikap yang ditunjukkan perempuan dalam instagram cenderung pada imitasi, euforia dan tindakan umum. Hal ini terlihat dari konten yang diunggapnya, seperti foto selfi yang menyerupai artis maupun selebgram, foto bersama keluarga dengan mengucapkan sambutan idul fitri yang menjadi bagian euphoria di bulan syawal, dan cover lagu menyerupai penyanyi idola yang digemari oleh para remaja, serta konten yang

16 Yenti Herlanti, "BlogQuest: Pemanfaatan Media Sosial pada Pembelajaran Sains Berbasis Sosiosaintifik untuk. Mengembangkan Keterampilan Beragumentasi dan Literasi Sains”, (Bandung: UPI, 2014), hal. 32

${ }^{17}$ Ilan Riss, "TYPOLOGY OF SOCIAL ACTIONS BASED ON THE LIVING SYSTEM THEORY," t.t., 13.

18 Godwin Emmanuel Oyedokun, "Management Thoughts: The Review of Social Action Theory," SSRN Electronic Journal, 2016, https://doi.org/10.2139/ssrn.2912274.4-5 
menunjukkan jiwa yang bosan karena karantina menjadi bagian dari proses reaksi pembentukan sikap remaja ketika musim pandemic covid 19,

Skema 1 Analisis Fenomenologi Sikap Remaja di Instagram

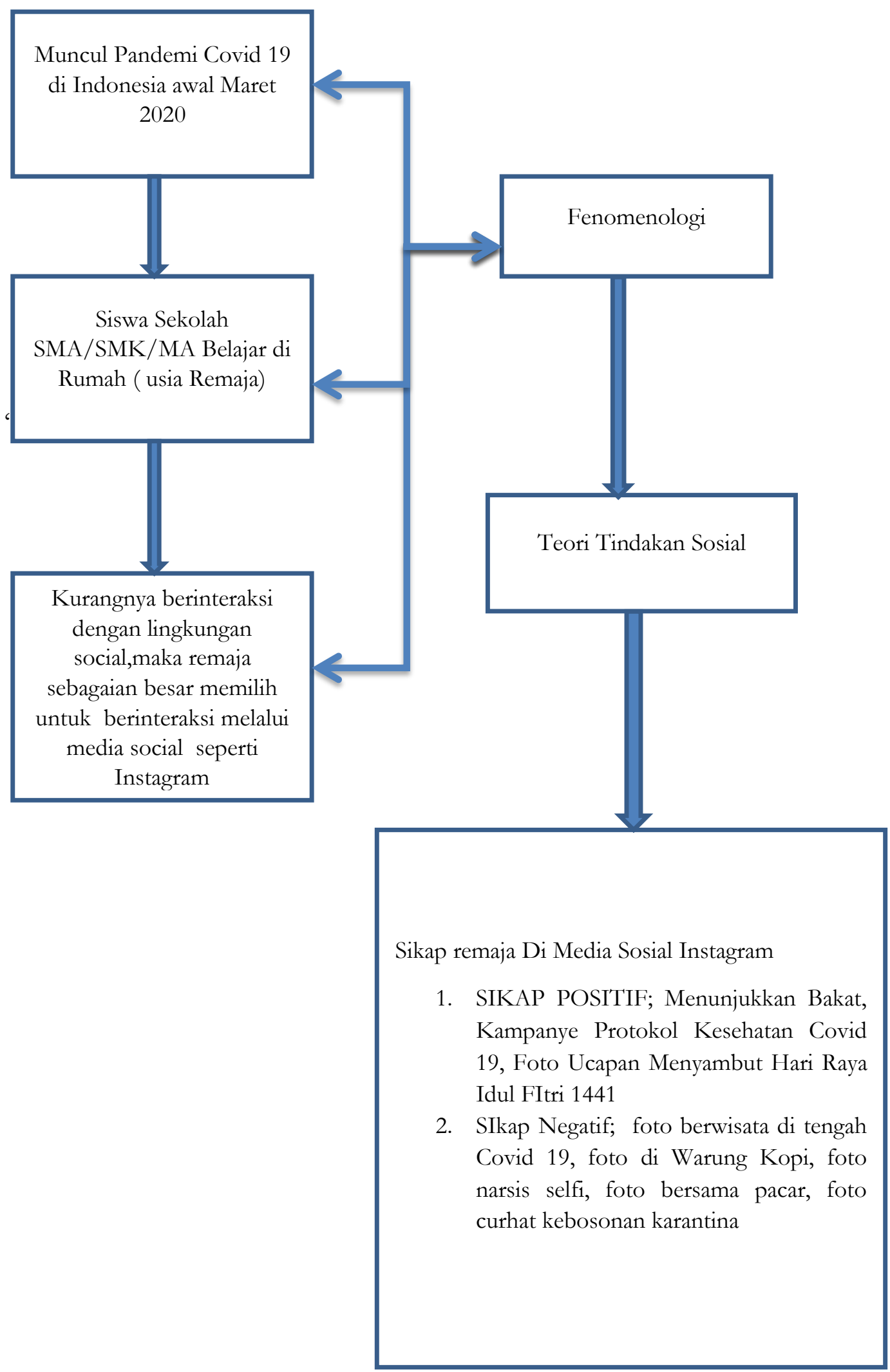

Jurnal Kopis: Kajian Penelitian dan Pemikiran Komunikasi Penyiaran Islam

Volume 03, Issue 1, Agustus 2020 


\section{Kesimpulan}

Munculnya Pandemi Covid 19 merubah segala aspek kehidupan masyarakat, dari usia anak-anak hingga usia lanjut diharuskan untuk mematuhi protokol kesehatan guna mencegah penyebaran covid 19 dengan cara mengurangi aktivitas di luar rumah. Salah satunya remaja yang awalnya melakukan pembelajaran di sekolah menjadi di rumah yang mempengaruhi berkurangnya interaksi social di luar. Media social menjadi wadah ekspresi dan rekreasi para remaja, salah satunya media social instagram. Sikap remaja di media social instagram pada musim pandemic covid 19 ditunjukkan bahwa sikap remaja laki-paki di media social instagram selama musim pandemic covid 19 cenderung mempresentasikan sikap positif, sedangkan remaja perempuan cenderung mempresentasikan sikap negatif, meskipun jumlah konten yang diposting antara remaja perempuan dan laki-laki relatif sama dalam segi kuantitas, akan tetapi dari segi kualitas sikap yang ditunjukkan sangat berbeda.

\section{Sitasi dan Daftar Pustaka}

Baron, RA, dan Byrne D. Psikologi sosial. 10 ed. Jakarta: Erlangga, t.t.

Cresswall, John W. Research Design Pendekatan Kualitatif, Kuantitatif, dan Mixed, Edisi Ketiga. Yogyakarta: Pustaka Belajar, 2009.

E.B, Gita Aprianta, dan Errika Dwi S.W. "Hubungan Penggunaan Media Sosial Dengan Tingkat Kepekaan Sosial di Usia Remaja.” The Messenger 9, no. 1 (2017): 65.

Fatnar, Virgia Ningrum, dan Choirul Anam. "KEMAMPUAN INTERAKSI SOSIAL ANTARA REMAJA YANG TINGGAL DI PONDOK PESANTREN DENGAN YANG TINGGAL BERSAMA KELUARGA” 2, no. 2 (2014): 5.

I., Cawidu. "Pemanfaatan media sosial.” Bandung: ipi.perpusnas.go.id, 2016.

Moleong, Lexy J. Metodologi Penelitian Kualitatif. Bandung: PT. Rosda Karya, 2008.

Netedu, Adrian. "TALCOTT PARSONS, THE THEORY OF SOCIAL ACTION AND THE THEORY OF RATIONAL CHOICE.” Talcott Parsons, 2010, 14.

Oyedokun, Godwin Emmanuel. "Management Thoughts: The Review of Social Action Theory.” SSRN Electronic Journal, 2016. https://doi.org/10.2139/ssrn.2912274.

Pertiwi, Wahyunanda Kusuma. "Sebanyak Inikah Jumlah Pengguna Instagram di Indonesia?" Kompas.com, t.t.

Riss, Ilan. "TYPOLOGY OF SOCIAL ACTIONS BASED ON THE LIVING SYSTEM THEORY," t.t., 13.

Setiawan, Erik, Fauziah Ismi Desiana, Widi Wulandari, dan Indah Salsabila. "Makna Hijrah pada Mahasiswa Fikom Unisba di Komunitas (followers') Akun 'LINE@DakwahIslam.”' MediaTor 10, no. 1 (2017).

Supriatna, Eman. "WABAH CORONA VIRUS DISEASE (COVID 19) DALAM PANDANGAN ISLAM.” SALAM: Jurnal Sosial dan Budaya Syar-i 7, no. 6 (14 April 2020). https://doi.org/10.15408/sjsbs.v7i6.15247. 
Susilo, Adityo, Cleopas Martin Rumende, Ceva Wicaksono Pitoyo, Widayat Djoko Santoso, Mira Yulianti, Herikurniawan Herikurniawan, Robert Sinto, dkk. "Coronavirus Disease 2019: Tinjauan Literatur Terkini." Jurnal Penyakit Dalam Indonesia 7, no. 1 (1 April 2020): 45. https://doi.org/10.7454/jpdi.v7i1.415. 